\title{
Correlation between Incidence of Diarrhea in Toddlers and Housewife's Clean and Healthy Lifestyle
}

\author{
${ }^{1}$ Teuku Alamsyah, ${ }^{1}$ Dewi Marianthi \\ ${ }^{1}$ Health Polytechnic of Aceh of Department of Nursing Banda Aceh, Indonesia \\ Corresponding author: T. Alamsyah, e-mail: alamsyah@poltekkesaceh.co.id \\ Co-author: DM: marianthi_dw@yahoo.com
}

Submitted: 16/03/2020 Revised: 02/04/2020 Accepted: 19/04/2020

Published online: $21 / 04 / 2020$

doi: https://doi.org/10.35308/j-kesmas.v7i1.1938 How to cite this article: Alamsyah, T., \& Marianthi, D. (2020). The Incidece of Diarrhea in Toddlers is Related ti The Clean And Health Lifestyle of Housewife. J-Kesmas: Jurnal Fakultas Kesehatan Masyarakat (The Indonesian Journal of Public Health), 7(1): 57-62.

\begin{abstract}
Diarrhea is one of the public health problems, particularly in infants. Based on the outcomes of the Aceh Besar fitness service survey, Baitussalam sub-district is one of the districts with a excessive wide variety of diarrhea cases, with a total of 520 instances in the one year. This is due to the lack of exact hygiene conduct related to hand washing cleaning soap in the prevention of diarrhea in toddlers. This research ambitions to find out the relationship between the clean and healthy lifestyle housewives on behavior of smooth water use and waste management with diarrhea in children of Baitussalam Subdistrict in Aceh Besar District, Indonesia. This is a descriptive analytic study using a case control study, consist of 28 moms who have children who suffer from diarrhea, and 28 moms who have youngsters do not go through from diarrhea. This lookup resulted in three findings namely there is a relationship between handwashing with cleaning soap with the incidence of diarrhea in infants (p-value $0.003<\alpha=$ OR 3.50), there is no relationship between the use of smooth water with the incidence of diarrhea in babies (p-value $1.00>\alpha=0.05$, OR 1.22) and there is a management relationship with the incidence of diarrhea in teens under five (p-value $0.01<\alpha=0.05$, OR 4.50).
\end{abstract}

Keywords: diarrhea in toddlers, clean and healthy life behavior, housewife

\section{Introduction}

Diarrhea is nonetheless the most motive of death within the world, accounting for 5-10 million deaths in a very year. The magnitude of the difficulty is considered from the high morbidity and mortality because of diarrhea (Hamzah et al., 2012) Almost altogether regions of the globe and every one age corporations are attacked with the help of diarrhea, however most of the objectives of this sickness are toddlers and toddlers, the place they trip a mean of 3-4 instances the incidence of diarrhea each year, but in some locations extra than 9 instances the incidence of diarrhea per 12 months is sort of $15-20 \%$ of a kid's lifestyles time spent on diarrhea (Thahirah, 2014).

According to data from the globe Health Organization (WHO) (2012) once a year there are greater than one billion instances of gastroenteritis. Diarrhea morbidity in 2011 was 411 sufferers per 1000 population. It's estimated that $82 \%$ of deaths because of rotavirus gastroenteritis show up in creating countries, specifically in Asia and Africa, where access to fitness and dietary fame is nonetheless an issue. Diarrhea are the range one reason of loss of life in children (31.4\%) and in toddlers $(25.2 \%)$, whilst altogether age corporations the wide range four purpose of loss of life $(13.2 \%)$ (Riskesdas, 2013)

According to the 2017 Indonesian Health Profile, the morbidity rate continues to be high, the morbidity survey conducted via the diarrheal infectious sickness subdivision stated the wide range of diarrhea sufferers in health facilities was once 7,077,299 people, while the number of diarrhea sufferers stated being handled at fitness facilities accustomed be 4,274,790 people or $60.4 \%$ of the target (Ministry of Health Republic of Indonesia, 2018)

Based on environmental health data, it is viewed from water usage per day and waste management. Compared to Riskesdas 2013, household water utilization $<20 \mathrm{~L}$ per man or woman per day reduced from $5 \%$ to $2.2 \%$. For waste management, households that control by means of burning are $49.5 \%$. and therefore the incidence of infectious illnesses like ARI, malaria and diarrhea in children decreased in comparison with the results of Riskesdas 2013. The prevalence of ARI dropped from $13.8 \%$ to $4.4 \%$, malaria fell from $1.4 \%$ to $0.4 \%$, 
as nicely like diarrhea in toddlers also dropped from $18.5 \%$ to $12.3 \%$ (Health, 2018)

In Indonesia, diarrhea is one in all the general public fitness problems, specifically in teenagers under five. Diarrhea is averted if the community can follow The Clean and Healthy Lifestyle (PHBS). (Kusumaningrum \& Hepiriyani, 2011). The Clean and Healthy Lifestyle (PHBS) launched by the authorities has been running for extra than 10 years, however its success is nonetheless a ways from expectations. From the information of the Aceh Besar health provider in 2017, it states that the data on Healthy Clean Living Behavior within the community within the working vicinity of the Baitussalam puskesmas is simply $33.2 \%$. This shows that the community within the working vicinity of the Baitussalam Puskesmas is nonetheless missing in clean and healthy behavior.

In the household, the predominant target have to practice behaviors which will create a PHBSBased Household, which incorporates deliveries assisted via medical examiners, giving toddlers exceptional breastfeeding, weighing children each and each month, the usage of easy water, washing hands with easy water and soap, managing ingesting water and ingesting within the household, the employment of healthy latrines (Stop Open Defecation), managing wastewater within the household, throwing garbage within the trash, eradicating mosquito larvae, ingesting fruits and greens daily, doing physical activities day after day, no smoking within the residence (Proverawati et al., 2012)

Maryunani (2013) noted that Handwashing with Soap (CTPS) Behavior could be a Clean and Healthy Life Behavior (PHBS) in a very number of settings along with household arrangements, school arrangements, institutions of health service institutions, or in other phrases handwashing with soap behaviors are sorts of PHBS is extremely important. Sunardi (2017) explained that hygiene habits or behavior by way of washing palms with cleaning soap (CTPS), can forestall the spread of infectious illnesses within the community, like diarrhea, belly typhus, intestinal worms, fowl flu, and even influenza which is now pretty horrendous to the globe.
Generally the villager solely use potluck water and not many personalities use soap to clean their fingers before or after the usage of the bathroom. a number of the matters above exhibit the reality that the conduct of washing fingers with cleaning soap united of the non-public hygiene efforts isn't but understood by the general public at giant and therefore the practice has now not been extensively utilized in day after day life Ratnawati et al. (2009). Safe water cure and storage at the household level can limit the incidence of diarrhea by means of $32 \%$ and efforts to increase the furnish of unpolluted water can limit the incidence of diarrhea by $25 \%$. Additionally, practising hand washing can limit the incidence of diarrhea by means of $45 \%$ (Hairani et al., 2017)

The results of research performed by using Selaras (2014) regarding the connection of sanitation of unpolluted water and maternal behavior toward the incidence of diarrhea in toddlers within the work vicinity of the neighborhood health core within the district of Setu, South Tangerang. That there's a full-size relationship between washing fingers with cleaning soap prior to / after doing with the incidence of diarrhea in children where the Pvalue got is 0.002 (Cita, 2014).

\section{Materials and Methods}

This research is descriptive analytic, with the type of case control research, comparing the case group and the control group. Case criteria are housewives who have toddlers who have suffered diarrhea recorded in the register book, which is located in the Work Area of the Baitussalam District, Aceh Besar District. The population of this study was housewives who had toddlers who had suffered diarrhea as a whole, amounting to 56 respondents who resided in the Baitussalam District, Aceh Besar District, Indonesia.

\section{Results \\ The incidence of diarrhea}

Univariate analysis was carried out on each variable from the results of the study using variables known that out of 56 respondents, the cases and controls were 28 respondents (50\%) each.

Table 1: Relationship of handwashing with soap behavior with the Incidence of diarrhea in toddlers (n 56)

\begin{tabular}{|c|c|c|c|c|c|c|c|c|}
\hline \multirow{4}{*}{ No } & \multirow{3}{*}{ Variable } & \multicolumn{4}{|c|}{ The incidence of diarrhea } & \multirow{3}{*}{ P-Value } & \multirow{3}{*}{$\alpha$} & \multirow{3}{*}{$\begin{array}{c}\text { OR } \\
95 \%(\mathrm{Cl}) \\
\end{array}$} \\
\hline & & \multicolumn{2}{|c|}{ Case } & \multicolumn{2}{|c|}{ Control } & & & \\
\hline & & $\mathrm{n}$ & $\%$ & $\mathrm{n}$ & $\%$ & & & \\
\hline & Behaviour & & & & & \multirow{3}{*}{0,03} & \multirow{3}{*}{0.05} & \multirow{3}{*}{$\begin{array}{c}3.80 \\
(1.25-11.50\end{array}$} \\
\hline 1 & Not good & 19 & 67.9 & 10 & 35.7 & & & \\
\hline 2 & Good & 9 & 32.1 & 18 & 64.3 & & & \\
\hline
\end{tabular}


Available at http://jurnal.utu.ac.id/jkesmas/issue/view/246

\begin{tabular}{|c|c|c|c|c|c|c|c|c|}
\hline & Use of Clean & & & & & & & \\
\hline 1 & Not eligible & 7 & 25.0 & 6 & 21.4 & & & 1,22 \\
\hline \multirow[t]{2}{*}{2} & Eligible & 21 & 75.0 & 22 & 78.6 & 1.00 & 0.05 & $(0,35-4,23)$ \\
\hline & Waste man & & & & & & & \\
\hline $\begin{array}{l}1 \\
2\end{array}$ & $\begin{array}{l}\text { Not good } \\
\text { Good }\end{array}$ & $\begin{array}{c}20 \\
8\end{array}$ & $\begin{array}{l}71.4 \\
28.6\end{array}$ & $\begin{array}{l}10 \\
18\end{array}$ & $\begin{array}{l}35.7 \\
64.3\end{array}$ & 0.01 & 0.05 & $\begin{array}{c}4,50 \\
(1.45-13.88)\end{array}$ \\
\hline
\end{tabular}

Source: Primary Data Processed

From the results of statistical tests using Chisquare, it is obtained that $p$ value is 0.03 . Because $p$ value $<0.05, \mathrm{Ha}$ is accepted, meaning that there's a major relationship between the variable behavior of Handwashing with Soap (CTPS) with the incidence of Diarrhea within the District health facility Work Area Baitussalam Aceh Besar Regency. Odd Ratio $(\mathrm{OR})=3.80(95 \% \mathrm{CI} 1.25-11.50)$. It shows that respondents who don't seem to be ok to behave handwashing with soap have a risk of three. 80 times greater occurrence of diarrhea than respondents who behave well.

From the results of statistical tests using Chisquare, $p$ value 1.00 was obtained because $p$ value $>$ 0.05 then Ha was rejected, meaning that there was no meaningful relationship between the variables of unpolluted water use and therefore the incidence of diarrhea in infants within the working area of
Puskesmas Baitussalam District Aceh Besar. Odd Ratio $(\mathrm{OR})=1.22$ (95\% CI 0.35-4.24), shows that because $95 \% \mathrm{CI}$ includes the amount 1 , the variable use of unpolluted water isn't necessarily a risk factor for diarrhea.

From the statistical test results using Chisquare, $\mathrm{p}$ value 0.01 is obtained because $\mathrm{p}$ value $<$ $0.05, \mathrm{Ha}$ is accepted, meaning that there's a meaningful relationship between the variable of household waste management and therefore the incidence of diarrhea within the working area of Baitussalam District, Aceh Besar Regency Year 2019. Odd Ratio (OR) $=4.50$ (95\% CI 1.45-13.88). Shows that respondents who don't seem to be good at managing household waste have a 4.50 times greater risk of developing diarrhea than respondents who manage well.

Table 2: Relationship of clean and healthy behavior with the incidence of diarrhea in toddlers ( $\mathrm{n}$ 56)

\begin{tabular}{clccc}
\hline No & \multicolumn{1}{c}{ PHBS } & P value & OR & 95\% (CI) \\
\hline 1 & Waste management & 0,01 & 4,50 & $1,45-13,88$ \\
2 & Handwashing Behavior Use Soap (CTPS) & 0,03 & 3,80 & $1,25-11,50$ \\
3 & Use of Clean Water & 1,00 & 1,22 & $0,35-4,24$ \\
\hline
\end{tabular}

Source: primary data processed

\section{Discussion}

\section{Relationship of handwashing with soap behavior with the incidence of diarrhea in toddlers}

From the results of statistical tests using Chisquare, $\mathrm{p}$ value obtained 0.03 , then $\mathrm{Ha}$ is accepted, meaning that there's a major relationship between the variable Handwashing with Soap (CTPS) with the incidence of diarrhea within the work area of the Baitussalam District of Aceh Besar District.

Promotion of hand washing (educational activities, sometimes with soap) in child care facilities or schools prevents about one third of episodes of diarrhea in high-income countries (rate ratio $0.70 ; 95 \%$ CI 0.58 to 0.85 ; nine trials, 4664 participants, evidence of high quality), and might prevent the identical proportion in LMICs but only two trials from urban Egypt and Kenya have evaluated this (rate ratio $0.66,95 \%$ CI 0.43 to 0.99 ; two trials, 45,380 participants, evidence of low quality). (Ejemot-Nwadiaro et al., 2015)

The results of this study are in line with research that mothers who have good handwashing habits are less likely to urge diarrhea the maximum amount as $19.3 \%$ compared to mothers who have poor handwashing habits at $64.7 \%$ (Kusumaningrum \& Hepiriyani, 2011) Similar research conducted by Luby, Agboatwalla, Bowen, Kenah, Sharker, and Hoekstra (2009), said that washing hands with soap consistently can reduce diarrhea and respiratory illness. Washing hands with soap can reduce diarrhea by $31 \%$ and reduce upper tract infections (ARI) by $21 \%$. Global research also shows that habits not only reduce, but prevent the incidence of diarrhea by up to $50 \%$ and ARI up to $45 \%$ (Purwandari et al., 2013)

Based on the results of the study it will be concluded that there's a relationship between handwashing with soap and diarrhea. a number of the respondents within the Baitussalam Puskesmas working area only wash their hands with water 
but don't use soap, and only wash their hands with soap if their hands look dirty. this can be also influenced by the habit of washing hands by employing a bowl of water or kobokan to scrub hands before eating by respondents while reception. Though the habit of washing hands with clean running water and soap can prevent disease, therefore the behavior of washing hands with soap with running water will be instilled or started from ourselves because this action is one among the behaviors of fresh and Healthy Life by cleaning hands and fingers using water and soap by humans to become clean and break the chain of germs.

\section{Relationship of the use of clean water with the incidence of diarrhea in toddlers}

Based on the results of the bivariate analysis, it are often seen that respondents who used water didn't meet the wants within the case group $25.0 \%$ greater than the control group $21.4 \%$, while respondents who used water fulfilled the wants within the case group $75.0 \%$ smaller compared to regulate group $78.6 \%$. From the results of statistical tests using Chi-square, $p$ value 1,00 was obtained then Ha was rejected, meaning that there was no meaningful relationship between the variables of fresh water use with the incidence of diarrhea in infants, poor water quality and diarrhea for the study utilized by escherichia as microbial water quality indicator, but not for people who use thermotolerant coliform.

However, although the analysis identified a major combined association, there was heterogeneity in individual associations, even for E. coli, with most studies showing a positive but no significant association (Levy, 2015) but not for those using thermotolerant coliform. However, while the analysis identified a major combined association, there was heterogeneity in individual associations, even for E. coli, with most studies showing a positive but no significant association, each water sanitation facility had each different requirement. , but from each of the prevailing requirements, the most requirement that has got to be considered is that the distance between the source of fresh water and also the disposal of feces (septi tanks) must not be but 10 meters.

This is in order that the source of fresh water used isn't contaminated by feces that contain many bacteria and worms which will cause diarrhea. (Hardi et al., 2012) Health benefits are limited because these drink sources could also be microbially contaminated and since basic sanitation might not be sufficient to guard the community (World Health Organization, 2014)
This shows that although the water used meets the wants, the incidence of diarrhea continues to be high. This is made clear by similar studies that say diarrhea can be influenced by three factors, namely environmental factors (clean water and toilet facilities), maternal risk factors (lack of data, maternal behavior and hygiene), and child risk factors (nutritional factors and breast feeding) exclusive) (Adisasmito, 2007). However, the results of this study don't seem to be in line with the results of Fajrina (2016) within the work area of the Idi Tunong Public medical institution in East Aceh Regency which said there was a relationship between clean water facilities and also the incidence of diarrhea.

Based on the results of research researchers assume that there's no relationship between the utilization of fresh water with the incidence of diarrhea. Because some communities have used water that meets the health requirements for clean water, many have used PDAM facilities because the family's main water source. Respondents who use ground water as their main water source also meet health requirements, the space from the well to the disposal of feces is quite 10 meters, in order that the utilization of fresh water doesn't cause diarrhea.

\section{The relationship of household waste management and the incidence of diarrhea in toddlers}

Based on the results of bivariate analysis it is seen that the share of respondents who don't seem to be good at managing household waste $71.4 \%$ is larger than the control group of $35.7 \%$, while the share of respondents who are good at managing household waste within the case group is $28.6 \%$ smaller than the control group $64.3 \%$. From the results of statistical tests using Chi-square, $p$ value obtained 0.01 , then $\mathrm{Ha}$ is accepted, meaning that there's a big relationship between the variable of household waste management and therefore the incidence of diarrhea within the work area of the Baitussalam District of Aceh Besar District.

According to Vivero et al. (2015), improper handling of waste can trigger high vector density numbers (flies, mice, cockroaches, mosquitoes, etc.) which may cause various health problems, one amongst which is diarrhea in infants because of toddlers' endurance weak. Flies is a vector within the spread of diseases including diarrhea. it's possibly that flies can breed and spread germs contained within the garbage to humans through food and other transmission media. Affirmed 
by Junias (2008) flies are one amongst the creatures that play a job within the spread of diarrhea events, acting as agents or mechanical vectors that only act as passive removal devices.

The results of this study are in line with studies in toddlers The prevalence of acute diarrhea in children aged 0-50 months within the study area is $11.9 \%$ and $94.6 \%$ of sanitation facilities don't seem to be improved. Sharing sanitation facilities by six or more households (AOR $=4.7 ; 95 \%$ CI: 2.4-9.4), proximity of sanitation facilities within 15 meters of a home (AOR $=6.6 ; 95 \% \mathrm{CI}: 2,5-17.0)$, presence of stool (AOR $=3.9 ; 95 \%$ CI: $1.5-10.3)$ and flies (AOR $=2.5 ; 95 \% \mathrm{CI}: 1.3-5.0)$ on the ground and/or around sanitation facilities, and therefore the presence of rubbish that's not collected in house compounds $(\mathrm{AOR}=3.2 ; 95 \%$ CI: $1.2-8.4)$ is significantly related to acute diarrhea. (Adane et al., 2017)

Based on the results of the study, the researchers assume that there's a relationship between waste management and therefore the incidence of diarrhea in infants, this is often because the way the waste is handled doesn't meet health requirements, where almost most respondents use trash cans that don't have a lid, so it can invite disease vectors like rats, flies, cockroaches etc. and for the management of liquid waste there are still many that don't meet the wants, where many of us who lose waste looking directly into the bottom don't have a reservoir.

\section{Conclusion}

This research reveals (1) there was a relationship between handwashing with soap (CTPS) of housewives and the incidence of diarrhea in infants, namely $(\mathrm{P}$-value $=0.03)(\mathrm{OR}=3.80)(2)$ there was no relationship between the use of housewives' clean water with the incidence of diarrhea in infants $(\mathrm{P}$-value $=1.00),(\mathrm{OR}=1.22)$ and (3) there is a relationship between housewife waste management and the incidence of diarrhea in infants, namely $(\mathrm{P}$ - value $=0.01),(\mathrm{OR}=4.50)$.

\section{Acknowledgement}

This research is done independently as a lecturer in Aceh Health Polytechnic, I am very grateful to Director H Ampera Miko MM, who has issued a letter of duty to the Public health center of Baitussalam Aceh Besar Districts

The researcher would like to give the deepest gratitude to the head and all employees of the Baitussalam Health Center, Aceh Besar, Indonesia and 56 housewives who became the sample of this study.

\section{Author Contribution and Competing Interest}

The author himself conducted all the process of this research. The author also declares that he has no financial or personal relationship(s) that may have inappropriately influenced him in writing this article.

\section{Publisher's Note}

J-Kesmas: Jurnal Fakultas Kesehatan Masyarakat (Indonesia Journal of Public Health) remains neutral with regard to jurisdictional claims in published institutional affiliation.

\section{References}

Adane, M., Mengistie, B., Kloos, H., Medhin, G., \& Mulat, W. (2017) Sanitation facilities, hygienic conditions, and prevalence of acute diarrhea among under- five children in slums of Addis Ababa, Ethiopia: Baseline survey of a longitudinal study. PLOS ONE, 1-18.

Kusumaningrum, A. \& Hepiriyani, \& Nurhalinah (2011) Pengaruh PHBS tatanan rumah tangga terhadap diare balita di kelurahan gandus palembang, Seminar Nasional Keperawatan I Universitas Riau, Pekan Baru - Indonesia, Page: 132-138.

Hairani, B., Suriani, S., Andiarsa, D. \& Juhairiyah, J. (2017) Hubungan pengetahuan ibu tentang diare dan perilaku memasak air minum dengan kejadian diare balita di Puskesmas Baringin Kabupaten Tapin tahun 2014. J. Health Epidemiol. Communic. Dis., 3(1): 10-14.

Cita, R. S. (2014) Hubungan sarana sanitasi air bersih dan perilaku ibu terhadap kejadian diare pada balita umur 10-59 bulan di wilayah puskesmas keranggan kecamatan setu kota tangerang selatan. Applied Microbiol. Biotechno., 85(1): 2071-2079.

Ejemot-Nwadiaro, R. I., Ehiri, J. E., Arikpo, D., Meremikwu, M. M., \& Critchley, J. A. (2015) Hand washing promotion for preventing diarrhoea. Cochrane Database of Systematic Reviews, 2015(9).

Hamzah, B., Arsin, A., \& Ansar, J. (2012) Diare pada balita di Kecamatan Belawa Kabupaten Wajo Tahun 2012 relationship clean and healthy behavior with the incidence of diarrhea in children under five years in sub district belawa district wajo 2012 Alumni Epidemiologi, Fakultas Kesehatan Masyarakat, 114.

Hardi, A. R., Masni, \& Rahma (2012) Faktor-Faktor yang mempengaruhi kejadian diare pada batita di wilayah kerja Puskesmas Baranglompo Kecamatan Ujung Tanah. FKM Unhas, 1-13. Retrieved from http://repository.unhas.ac.id/bitstream/handle/12345 6789/4666/Jurnal Fix Amin Rahman Hardi 
$\% 28 \mathrm{~K} 11107156 \% 29$.pdf? sequence $=1$

Kemenkes RI. (2018) Provil Kesehatan Indonesia 2018. https://doi.org/10.1002/qj

Levy, K. (2015) Editorial: Does poor water quality cause diarrheal disease? Am. J. Trop. Medicine and Hyg., 93(5): 899-900.

Purwandari, R., Ardiana, A., \& Wantiyah. (2013) Hubungan antara perilaku mencuci tangan dengan insiden diare pada anak usia sekolah di Kabupaten Jember. Keperawatan Universitas Jember, 4(2), 122-130.

Riskesdas. (2013) Riset Kesehatan Dasar (RISKESDAS) 2013. Laporan Nasional 2013, 1. https://doi.org/10.3406/arch.1977.1322

Sunardi, F. R. (2017) Perilaku mencuci tangan berdampak pada insiden diare pada anak usia sekolah di Kabupaten Malang. J. Universitas Muhammadiyah Malang, 8(1): 85-95.
Thahirah. (2014). Hubungan Perilaku Hidup Bersih dan Sehat (PHBS) dengan kejadian diare pada anak di SD Integral Al-Bayan Yayasan Al-Bayan Pondok Pesantren Hidayatullah Makassar. Jurnal Keperawatan, 1-68.

Vivero, R. J., Torres-Gutierrez, C., Bejarano, E. E., Peña, H. C., Estrada, L. G., Florez, F., ... Muskus, C. E. (2015) Study on natural breeding sites of sand flies (Diptera: Phlebotominae) in areas of Leishmania transmission in Colombia. Par. Vect., 8(1). https://doi.org/10.1186/s13071-015-0711-y

World Health Organization (2014) Preventing diarrhoea through better water, sanitation and hygiene. World Health Organization, 1-48. Retrieved from http://apps.who.int/iris/bitstream/10665/150112/1/97 89241564823 eng.pdf?ua $=1 \& u a=1$ 